vice in cases of further marriage) and the Synod accordingly gave general approval to the rescission of the relevant parts of those regulations. Under the provisions of Article 7 of the Synod's Constitution, the resolution to that effect was subsequently referred to the House of Bishops, with the possibility of the Convocations and the House of Laity calling for a reference of the business to them before it is taken back to the Synod for final approval.

\title{
THE GOVERNING BODY OF THE CHURCH IN WALES
}

\author{
CHARLES ANDERSON \\ Solicitor to the Province of Wales
}

\begin{abstract}
This report covers the meetings of the Governing Body in April and September 2002.
\end{abstract}

\section{April 2002}

The April meeting was confined to a single day of formal business, the Standing Committee having reached the conclusion that with a relatively light agenda on this occasion, it was a more efficient use of resources to have one full day's business than spread the work of the session over two days. The meeting took place shortly after the death of Her Late Majesty Queen Elizabeth the Queen Mother and at the start of the meeting all present stood in silence as a mark of respect to her.

Two private member's motions were proposed. The first, taking note of the then imminence of the Earth Summit 2002, called for a letter endorsing the aims of the Summit to be sent to the Prime Minister, to the First Minister of the National Assembly for Wales and to the United Nations and urged each diocese, deanery and parish to mark the occasion of the Summit with acts of worship and prayer and also encouraged parishes to consider joining the Eco-congregation Environmental Action Programme.

The second motion looked to the continuing instability and violence in Israel/ Palestine and the resulting implications for vulnerable groups and communities and urged the case for prayer and negotiation to resolve the problems. This resolution had originally been tabled for consideration at the Governing Body's meeting in September 2001 but was withdrawn on that occasion following the events of September 11 which were noted in an emergency motion.

Both of these motions were discussed and both passed without opposition.

Apart from various regular business items, the other item of note on the agenda for April was a presentation on the proposals to create an Ecumen- 
ical Bishop for the Local Ecumenical Projects in East Cardiff. The presentation was led by the Bishop of St Asaph, supported for the Church in Wales by the Revd Marian Dowsett and the Revd Robert Paterson in his capacity as Principal Officer of the Council for Mission and Ministry. They were joined in the presentation by the Revd Dr Siôn Aled Owen for Cytun, the Revd Will Morrey for the Methodist Church, the Revd Stuart Jackson for the United Reformed Church and the Revd John Garland for the Covenanted Baptists. The Bill to set up the role being due to come before the Governing Body in September 2002, this presentation was designed as a way of explaining the scheme and its background to members to provide an opportunity to discuss it prior to having to consider and vote upon the Bill itself.

\section{September 2002}

In contrast to April the agenda for this meeting was very heavy. A presentation was made by a group on behalf of the Council for Mission and Ministry under the title 'On a Journey'. The consultation document of this title, which was the subject of the presentation, had as its aims the search for the answers to the three questions:

- What are God's intentions for the world and the church?

- What is the mission of the church in God's world?

- How do we organise ourselves to carry out God's purposes?

The report and the presentation looked at the shape and activity of present day society, what the church's mission in such a society might be, how it could be fulfilled and the ministry necessary to guide that fulfilment. The ideas set out in the report and explained in the presentation are the result of over a year's work by the groups who prepared them. Significant time was given to them in the Governing Body's programme and they were accorded a warm reception.

Later in the first day of the meeting the annual report of the Representative Body was presented. As well as introducing the annual report itself and commenting on the implications of the still straitened financial position, the Chairman, Mr Richard Parkinson, introduced individual Sub-committee Chairmen to comment on the work of their respective Sub-committees. $\mathrm{Mr}$ Parkinson then formally proposed a revised ethical investment policy statement and called upon the Revd Dr John Holdsworth, as Chairman of the group which had prepared the statement, to explain the detailed thoughts behind it. The Governing Body approved the statement without opposition. Thereafter the Ven Hywel Jones, Archdeacon of Cardigan and Chairman of the Churches Sub-committee, introduced proposals to amend the Churchyard Regulations to take account of proposals put forward by a working group comprising members of the Maintenance of Ministry and Churches Sub-committees. The proposals were brought to the Governing Body in principle and after discussion were accepted with a number of suggestions. These will all now be considered by the Drafting Sub-committee prior to 
being reported to the Standing Committee at its next meeting prior to being referred back to the Governing Body for detailed approval.

This part of the proceedings having been concluded, the Archbishop drew members' attention to the fact that this was the final occasion when $\mathrm{Mr}$ Parkinson would present and introduce the Representative Body's report as he was due to retire as Chairman of the Representative Body at the end of September, having discharged these onerous responsibilities for the last ten years. The Governing Body responded warmly to the Archbishop's tribute to Mr Parkinson, to whom it had fallen to guide the Representative Body through difficult financial times, and wished him and Mrs Parkinson well for the future.

The second day's business was concerned principally with the committee stage and the vote on the Bill to provide for the authorisation of an Ecumenical Bishop for the Local Ecumenical Projects in East Cardiff. This was the Bill for which the presentation in April had been an introduction. By its nature the Bill was one which allowed little scope for detailed amendment and most of the discussion came on the motion that the Bill be passed. A great many speeches were made during this part of the debate. In a subject on which inevitably strong feelings were held respectively in favour of and against the proposal, the debate was notable for an atmosphere of respect for the opposing views. In the end the Bill failed to obtain the requisite majority and was lost.

The remainder of the day was taken up with a presentation of proposals for an alternative calendar, lectionary and collect and a number of reports. Proceedings closed with a presentation led by the Bishop of Llandaff and the Chairman of the Standing Committee to the Archbishop and Mrs Williams. this having been the last meeting of the Governing Body over which the Archbishop would preside prior to his translation to Canterbury.

\title{
THE GENERAL SYNOD OF THE SCOTTISH EPISCOPAL CHURCH
}

\author{
IVOR GUILD \\ Writer to the Signet
}

A Eucharist set the Synod in motion, the preacher being the Bishop of Manicaland, Zimbabwe. A formal welcome by the Primus followed, in which he encouraged the Synod, since conflict was intrinsic to human experience, to engage in it creatively and in a way which would enliven the mission of the Church. The good wishes of the Synod were then sent to Her Majesty the Queen in this her golden jubilee year. A break ensued for lunch before the Synod pursued its agenda. 